\title{
The importance of belief dispersion in the response of gold futures to macroeconomic announcements
}

\author{
${ }^{* *}$ Lee A. Smales, CFA \\ School of Economics \& Finance \\ Curtin University \\ Building 402 \\ Kent Street \\ Perth \\ WA 6845 \\ Australia \\ lee.smales@curtin.edu.au \\ ${ }^{* *}$ Corresponding Author
}

\author{
Yi Yang
}

School of Economics \& Finance
Curtin University
Building 402
Kent Street
Perth
WA 6845
Australia
ivan.yang@curtin.edu.au
yangyi199183@gmail.com

We investigate the behaviour of trading in gold futures around the release of macroeconomic announcements. Market activity, in terms of traded volume, returns, and volatility, responds to new information quickly, with the majority of the reaction complete within 90 -seconds. Surprises on the unemployment rate have the largest impact, with the market witnessing greater reactions to 'good' news and a weaker response during recession. Importantly, by employing a novel measure of belief dispersion, we are able to show that the market response to macroeconomic news is significantly increased when belief dispersion is wider.

Keywords: Gold futures; Macroeconomic announcements; Belief dispersion; COMEX; Highfrequency

JEL Codes: G10; G14 


\section{Introduction}

Since time immemorial gold has played an important role in society; early civilisations equated gold with gods and used the precious metal as a sacrificial offering. In modern times gold remains a widely utilized store of value and means of exchange, and has been widely used as a hedge against inflation, protection against exchange-rate risk (Capie et al., 2005) and for portfolio diversification (McCown and Zimmerman, 2006; Draper et al. 2006). Both the financial media and academics (Baur and Lucey, 2010; Baur and McDermott, 2010) have cited the important role of gold as a safe haven during times of crisis. The emergence of financial instruments, such as exchange traded funds (ETFs), has resulted in an ever-increasing number of institutional and retail investors participating in the gold market. For example, the largest Gold ETF (State Street's SPDR Gold Shares) had a market value of over $\$ 32$ billion as at mid-2014, and physical gold demand for investment purposes now constitutes approximately $35 \%$ of total demand for the metal. In order for investors to make rational portfolio optimization choices it is necessary to have an understanding of how macroeconomic news events impact returns, the volatility of those returns, and the level of trading activity, as well as the conditions that influence the efficiency of market pricing.

Motivated by the growing importance of the gold market, this paper explores the reaction of market activity in the gold futures market around the release of U.S. macroeconomic announcements. Several important questions are addressed. First, what is the impact of macroeconomic news on the returns, realized volatility, and trading volume of gold futures? How quickly does this reaction occur, and how long does it persist? Second, is there a differential response to news that is perceived to be bad or good for economic growth? Third, is the impact state dependent with regards the condition of the macro-economy? Finally, is the dispersion of beliefs around macroeconomic announcements important in determining market activity?

Owing to its importance in price formation, the incorporation of economic news into asset prices has been the subject of extensive research for more than three decades; the role of scheduled macroeconomic announcements has been frequently examined since such news events are readily identifiable and have implications for market efficiency. Market efficiency dictates that the expected portion of an announcement should have no effect on asset prices, instead it is the surprise (news) component that the market responds to. Empirical evidence is supportive of 
this claim with Kim et al. (2004), Fatum and Scholnick (2008), Chen et al. (2013), and Smales (2013) reporting that asset returns primarily respond to the news component.

Much of the extant literature has focused on the stock, bond, and foreign exchange markets. Flannery and Protopapadakis (2002) employ a GARCH model of daily U.S. equity returns to identify the importance of macroeconomic news and report that only the money supply affects both the level and volatility of returns. Employing a similar framework, Nikkinen et al. (2006) discover that global stock markets, particular those in major markets, also respond in a statistically significant way to U.S. macroeconomic news. Nikkinen and Sahlström (2004) extend the analysis to measures of stock market uncertainty (VIX) and Chen et al. (2013) consider U.S. stock futures, with both reporting that announcement surprises are found to have a significant impact.

Considering the fixed income market, Fleming and Remolona (1999) report that the release of macroeconomic news has a substantial effect on prices and trading activity, while Becker et al. (1996) and Balduzzi et al. (2001) show that a number of economic announcements affect U.S. Treasury bond prices, with inflation and employment data having the largest impact. Andersen et al. (2003) examine the relationship between macroeconomic news and the U.S. dollar exchange rate against six major currencies, while Galati and Ho (2003) and Ehrman and Fratzscher (2005) consider the euro-dollar exchange rate response, reporting that U.S. macroeconomic news tends to have a greater impact on returns and volatility than that from other countries.

While commodities such as gold are not financial assets, the results from other markets are still relevant given the relationship between commodity prices and financial asset valuations, and the increasing financialization of commodities in general and gold in particular. Frankel (2008) argues that one channel through which this effect is accomplished is the negative effect of interest rates on the desire to carry commodity inventories. Limited attempts have been made at investigating the impact of macroeconomic news on commodity prices. For instance, ChristieDavid et al. (2000) use intraday data to document the response of gold and silver futures, indicating that gold prices respond to the news component of releases for the consumer price index, gross domestic product, the producer price index, and the unemployment report. Similar results are reported by Cai et al. (2001) regarding intraday return volatility, and also note personal income as having a significant impact. Roache and Rossi (2010) note that commodity prices are generally not influenced by economic news but the sensitivity has risen as commodities have become increasingly financialized. Most recently, Elder et al. (2012) consider the gold, silver and 
copper future markets for the period 2002-2008 and report that the response to economic news is both swift and significant, and also that announcements reflecting an unexpected improvement in the economy tend to have a negative impact on gold and silver prices.

An asymmetric effect whereby 'bad' news for economic growth has a greater impact than 'good' news has been noted in the extant literature (Ederington and Lee, 1995; Andersen et al., 2003; Brenner et al., 2009; Riordan et al., 2013; Smales, 2014a). Roache and Rossi (2010) suggest that the asymmetric response for gold is a result of its status as a "safe-haven". Additionally, there is significant evidence that the response of asset prices to macroeconomic news is dependent on market conditions as well as the general state of the economy. McQueen and Roley (1993) note this effect in the U.S. stock market, while Cook and Korn (1991) and Roley and Sellon (1995) find the relationship for long-term rates varies over the business cycle as market participants alter their views on the persistence of monetary policy actions. Hess et al. (2008) show that daily commodity prices are responsive only during recessionary periods.

Whilst the literature considering the impact of macroeconomic news is extensive and has incorporated a number of asset-types, along with the influence of the economic cycle and asymmetric news effects, it has largely ignored another important strand of the finance literature; namely heterogeneous beliefs. Starting with Varian (1985) and Karpoff (1986), there have been several attempts at developing theoretical models linking market activity with the level of disagreement among investors. Shalen (1993) develops a rational expectations model in which dispersion is positively related to changes in volume, volatility and absolute price changes, Harris and Raviv (1993) propose a model of trading in speculative markets based on differences of opinion, while Kandel and Pearson (1995) derive a similar model that suggests trading volume in stocks and their related options is dependent on investor belief of future stock volatility.

Empirical evidence regarding the impact of beliefs on market activity is focused on equity markets and the response to earnings announcements, with analyst forecasts of reported earnings acting as a measure of belief dispersion. Kazemi (1991) and Rees and Thomas (2008) find that asset prices are negatively associated with dispersion of beliefs, while Bildersee et al. (1996) show that trading volume is positively associated with earnings precision and contemporaneous dispersion of beliefs. More recently, Banergee (2007) and Sarkar and Schwartz (2009) have jointlydetermined that belief dispersion is positively related to absolute returns, return volatility and volume. While Chen et al. (2013) discuss the importance of analyst surveys on macroeconomic 
data produced by Bloomberg, they focus on accuracy and ignore the range of forecasts; indeed the only work to have considered dispersion of macroeconomic opinions is that of $\mathrm{Li}$ and $\mathrm{Li} \mathrm{(2013)}$ who report that belief dispersion among households is positively related to stock trading volume.

The existing literature is developed in several important ways: First, despite the phenomenal growth in the use of the gold market for investment purposes there is a lack of studies examining the role of information arrival on the gold futures market. Second, our analysis is based on high-frequency data based on 10-second and 30-second intervals. This increased granularity of data allows for the detection of market reactions that are not so easily investigated with lower frequency data. Indeed, the only three prior uses of intraday data in the gold futures context use 15 -minute and 5 -minute ${ }^{1}$ intervals and acknowledge that the majority of the reaction is over within the first interval; research in other markets (e.g. Ederington and Lee, 1993; Smales, 2013) suggest that the response is much more rapid, and with the increased use of faster trading technology it is important to gain a more accurate understanding of the response time-frame. Third, to our knowledge, this paper is the first to apply the theory of heterogeneous beliefs to macroeconomic news, and also the first to consider the role of belief dispersion in market activity outside of the equity markets. In sum, by considering high frequency data, the importance of disaggregated news, the relevance of economic state dependence, and the significance of belief dispersion, this study provides the most comprehensive study into the effects of macroeconomic news on gold futures to date.

The key findings may be summarized as follows. First, macroeconomic news plays an important part in determining the level of market activity as encapsulated by trading volume, returns, and volatility of returns; this response is almost immediate and subsides within the first 90-seconds following the announcement. Consistent with previous results gold futures tend to react positively to unexpectedly bad news, and positively to announcements reflecting an unexpected improvement in the economy. Second, the surprise element of unemployment rate news has a particularly significant effect on market activity, with CPI and GDP closely following; the importance of unemployment news may be at least partially explained by the use of language targeting unemployment levels in Federal Reserve monetary policy. Third, contrary to the extant literature in traditional asset classes, the response of market activity seems to be stronger in the

\footnotetext{
${ }^{1}$ Christie-David et al. (2001) use 15-minute intervals; Cai et al. (2001) and Elder et al. (2012) use 5-minute intervals.
} 
presence of good (rather than bad) news and weaker during recession, providing evidence to the claims that investors use gold as a safe-haven. Finally, the empirical results demonstrate a positive relationship between belief dispersion and market activity; that is as the dispersion of beliefs around an announcement become wider there is an increase in market activity.

The remainder of this paper is organized as follows: The next section presents the data used in the empirical study. Section 3 presents a graphical motivation for the study together with the empirical results. Section 4 offers tests of robustness for the reported results, and Section 5 concludes.

\section{Data}

\subsection{Data for the Gold Futures Market}

The empirical analysis in this paper considers the gold futures market ${ }^{2}$; the most actively traded gold futures are those traded on COMEX (owned by the Chicago Mercantile Exchange since August 2008), where the contract size is 100 troy ounces and the minimum price fluctuation is $\$ 0.10$ per troy ounce. Settlement takes place via physical delivery on any business day during the current delivery month, with trading for the near (current) contract terminating on the third last day of the delivery month.

Transaction level data for gold futures are obtained from Thomson Reuters Tick History (TRTH) provided by SIRCA ${ }^{3}$ for the period $24^{\text {th }}$ November $2006^{4}-31^{\text {st }}$ December 2012, a total of 1,532 trading days; for the data used in this sample the nearest-to-maturity contract is used and switched to the second-nearest contract when open interest becomes greater. Figure 1 depicts the evolution of the price of gold futures over the six-year sample period, with a clear up-trend apparent from August 2007 to August 2011, as the gold price nearly trebled from $\$ 640$ to over $\$ 1,830$, followed by a period of consolidation. The National Bureau of Economic Research (NBER) defined the U.S. economy as in recession from October 2007 to June 2009.

\section{$<$ Insert Figure 1 - Price Chart $>$}

The transaction level data is used to calculate the variables of interest for 10-second (30second) intervals in the 12-minutes (1-hour) surrounding macroeconomics announcements; the

\footnotetext{
2 Reuters symbol GC.

${ }^{3}$ Securities Industry Research Centre of Asia-Pacific

${ }^{4}$ TRTH transaction data for gold futures is incomplete prior to this date.
} 
10-second intervals run from 2-minutes prior to the identified announcements to 10 -minutes after, while the 30 -second intervals run from 15 -minutes before the announcement to 45 -minutes after. For each interval, the following is computed:

$R_{t}$ : the return for the futures contract during interval $t$, calculated using the mid-point of the bid-ask spread ${ }^{5}$, defined as $R_{t}=\log \left(P_{t} / P_{t-1}\right)$;

Volatilityt: the realized volatility for the futures contract during interval $t$, calculated as the time-weighted standard deviation of bid-ask midpoints in the interval;

Volumet: the total volume of contracts traded during interval $t$.

Summary statistics for the gold futures market variables are provided in Panel A of Table 1. For both 10 -second and 30 -second intervals the average return is close to zero, there is evidence of a high degree of kurtosis (fat-tails) typical of asset price returns, and no significant evidence of return autocorrelation. High degrees of skewness, kurtosis, and positive autocorrelation are apparent for both volatility and volume measures; such results are typical of the volatility clustering identified in time-series by Engle (1982) and Bollerslev (1986). For all three variables the unit root is rejected at a high level of significance.

$<$ Insert Table 1 - Summary statistics >

\subsection{Macroeconomic News}

Data for major macroeconomic announcements, together with the survey results of market expectations for each of the announcements is collected from Bloomberg. My sample of announcements is restricted to those announcements identified in Cai et al. (2001) as having a profound impact on the intraday dynamics of the gold futures market; Consumer Price Index $(C P I)$, Gross Domestic Product $(G D P)$, and the Unemployment Rate $(U N E M P)^{6}$. Producer Price Index $(P P I)$ is also included as several studies (e.g. Flannery and Protopapadakis, 2002; Nikkinen and Sahlström, 2004) have indicated its importance in non-commodity markets, and ChristieDavid (2000) demonstrate the role of Personal Income (PINC). All announcements occur at 08:30AM (EST), just 10-minutes after the official market open.

\footnotetext{
${ }^{5}$ The mid-point is used in order to reduce the effect of the bid-ask bounce.

${ }^{6}$ In general, the literature has found CPI, GDP, PPI and the unemployment rate to be the announcements having the greatest impact on asset prices. The unemployment report is of particular importance with the majority of studies in this field (e.g. Cook and Korn, 1991; Krueger, 1996; Ederington and Lee, 1993, 1995; Becker et al., 1996; Christie-David et al., 2000; Balduzzi et al., 2001; Cai et al., 2001; Nikkenen and Sahlström, 2004; Elder et al., 2012) noting the significant impact on market activity.
} 
Market efficiency dictates that the expected portion of an announcement should have no impact on asset prices, and the extant literature (Kuttner, 2001; Andersen et al. 2003; Smales 2013) has provided ample empirical evidence to the effect that asset prices react to the surprise component of macroeconomic announcements; this news component is the focus of this paper. Following Balduzzi, Elton, and Green (2001), the news component is standardized to allow for comparison of coefficients on announcements with different magnitudes. In particular, for announcement type $k$ on day $t$, news is defined as:

$$
N_{k t}=\frac{A_{k t}-E_{k t}}{\sigma_{k}}
$$

Where $A_{k t}$ is the actual value of the macroeconomic announcement, $E_{k t}$ is the (Bloomberg) market survey expectation, and $\sigma_{k}$ is the standard deviation of the news component $\left(A_{k t}-E_{k t}\right)$. Thus, an announcement surprise equal to 1.0 implies a surprise that is one standard deviation greater than zero for that announcement type. In addition, following Elder et al. (2012), the news components are calibrated so that a positive value represents data that is stronger than expected with regards economic growth (i.e. more inflationary), and a negative value represents weaker than expected economic growth (i.e. less inflationary); this allows for easier comparison of the coefficients. In our case, the only news component affected is that for the unemployment rate announcement, so that a positive surprise represents an unemployment rate that is lower than expected.

Finally, a novel measure for the dispersion of beliefs within the market at the time of the announcement is introduced; the standard deviation of analyst forecasts for the given announcement $k$ on day $t$, is standardised using the mean standard deviation of analyst forecasts for the announcement $k$ over the whole sample period ( $k_{-}$dispersion). Descriptive statistics for each of the macroeconomic news variables are provided in Panel B of Table 1. The average measure of forecast dispersion is largest for the producer price index (0.301) and smallest for the unemployment rate (0.093). The news component of the data release (calculated using Eq.(1)) is negative on average for the unemployment rate but positive for all other macroeconomic news events; also of note is that the standard deviation of the news component is relatively high.

\section{Empirical Results}

\subsection{An illustrative motivation}

To examine the impact of announcements on trading volume and realized volatility, I consider intervals aligned in event time, with the release of the announcement occurring at time 
zero. In the first instance, I consider a series of figures that depict unconditional trading volume and volatility responses to the arrival of macroeconomic news. The figures provide initial evidence as to the hypothesized relationships from Section 2.

\section{$<$ Insert Figure 2>}

Figure 2 depicts trading volume and realized volatility in the period around the release of major economic announcements; days without such announcements are considered for comparative reasons. The two charts on the left depict 10 -second intervals $(-2 \mathrm{~min},+10 \mathrm{~min})$, while the charts on the right depict 30 -second intervals $(-15 \mathrm{~min},+45 \mathrm{~min})$. In the period immediately prior to the announcement, volume and volatility tend to be lower than at the same time on days without announcements. As the announcement is made there is a significant spike in volume and volatility (volume increases by $405 \%$, and volatility by $220 \%$ for 10 -sec intervals). Volume and volatility peak in the first interval $(0,10)$, and then declines to a level that is generally higher but statistically indistinguishable from that on non-announcement days within 90 seconds (60 seconds for volatility); this preliminary result indicates that the existing literature which has used longer time intervals may lose some of the interesting granularity. The 30 -second charts indicate that there is also a jump in volume and volatility upon the opening of the pit at 08:20AM, however the increase is greater and more persistent following major macroeconomic announcements.

\section{$<$ Insert Figure 3>}

Having identified that the presence of major macroeconomic announcements results in significant jumps in volume and volatility, I turn to consideration of the impact of dispersion of market beliefs around those announcements. Figure 3 depicts volume and volatility for 10 -second and 30-second intervals around major macroeconomic announcements, with high dispersion indicating the occasions on which the standard deviation of analyst forecasts is in the highest quintile and low dispersion indicating when standard deviation is lowest. Even though a major announcement occurs in both cases, the market response is much sharper when there is a high degree of belief dispersion; the results converge more quickly than when comparing announcement days with non-announcement days. This is the first piece of evidence suggesting that belief dispersion plays an important part in the gold futures market response to macroeconomic announcements.

$<$ Insert Figure 4> 
The prior literature has identified an asymmetric response to news whereby the stock, bond, and currency markets respond more vigorously to negatively perceived news than to positive news. Figure 4 presents initial evidence as to whether this same relationship also holds for the gold futures market. The only period in which there is a statistically significant difference is in the first 10 seconds after the data release $(0,10)$ when volume traded and realized volatility is greater when macroeconomic announcements provide news that is worse than expected (negative) with regards economic growth; the fleetingness of this difference means that it is not detected when considering 30-second intervals.

In summary, the presented figures suggest that there is a significant response of trading volume and volatility to macroeconomic announcements that quickly dissipates; this response is stronger when there is a high level of dispersion among analysts regarding the announcement. In addition, the asymmetric response to negative news is indistinguishable if considering intervals longer than 10 -seconds.

\subsection{Baseline regression}

To formally assess the importance of the surprise component of macroeconomic announcements, and the dispersion of beliefs around the announcement, on the gold futures market we utilise regressions of the following form:

$$
y_{t}=\alpha+\sum_{k=1}^{5}\left(\beta_{k} \text { News }_{k t}+\beta_{k+5} \text { Dispersion }_{k t}\right)+y_{t-1}+\varepsilon_{t}
$$

Where $y_{t}$ is the dependent variable of interest in the 10-second interval $t$ (the natural log of traded volume, volatility, or returns), Newskt is the news component, calculated as in Eq. (1), for announcement $k$ at time $t$, Dispersion $k t$ is the standardized standard deviation of analyst estimates for announcement $k$ at time $t, y_{t-1}$ is the lagged dependent variable, and $\varepsilon_{t}$ is the error term.

While there is a clear theoretical construct as to how macroeconomic news should affect the volatility and direction of stock and bond prices, Elder et al. (2012) note that for commodity prices the direction of the impact is indeterminable ex-ante. For instance, announcements that indicate good (better than expected) news for economic growth may result in higher inflation expectations that lead investors to shift into physical assets like commodities (inducing positive 
returns) or alternatively may increase real interest rates which increases the cost of carry, reduces economic growth and drives down commodity prices (negative returns).

$<$ Insert Table 2>

Empirical results for the 12 -minute period $(-2,+10)$ are reported in Table $2^{7}$. Consistent with the autocorrelations identified earlier, each of the lagged dependent variables is positive and highly significant. In the absence of an announcement, returns are statistically indistinguishable from zero, while volume and volatility are significantly positive. When dispersion is not considered, unemployment news has a significant and positive impact on both volume and volatility; that is, as the market is more surprised by the release of the unemployment rate volume and volatility increase. All other news releases serve to increase volume and volatility but the relationship is not significant.

When variables accounting for the dispersion of beliefs are included the unemployment news variable is no longer well-defined. Instead, dispersion coefficients for CPI, GDP and the unemployment rate have positive and significant relationship with volume, volatility and returns; personal income and PPI dispersion also significantly influence volume. The importance of belief dispersion, or uncertainty, in the unemployment rate announcement is demonstrated by the magnitude of the coefficient being at least three times greater than the next largest.

$<$ Insert Table 3>

Prior research has found that disaggregating news into negative and positive components reveals detail that may be hidden by aggregated variables, and also allows for investigation of asymmetric news effects. Table 3 reports results for a regression specification whereby eq. (2) is augmented by the disaggregation of news variables ${ }^{8}$; results are reported for the whole sample period and also for the period defined as recessionary by the NBER. Once again, each of the lagged dependent variables is positive and significant, and in the absence of macroeconomic news returns are not significantly different from zero, and both volume and volatility are positive.

\footnotetext{
${ }^{7}$ Results for the 30 -minute period $(-15,+45)$ using 30 -second intervals are not reported here but are qualitatively similar.

${ }^{8}$ Negative (positive) news variable takes a value equal to the news component when it is negative (positive) and zero otherwise.
} 
Considering the whole sample period first, unemployment news (both negative and positive) is the only news-type to affect all three dependent variables, and also has the coefficients with the largest magnitude. Negative and positive GDP news have a significantly positive impact on volatility, as does negative (weaker than expected) CPI news, while negative GDP news also positively induces volume. Echoing results in Elder et al. (2012) and Smales (2014b), gold futures tend to react positively to unexpectedly bad news, and positively to announcements reflecting an unexpected improvement in the economy; apart from unemployment where both components are well-defined only the positive news components of CPI, GDP, and PPI are significant.

When dispersion factors are considered the prior results are confirmed, namely that dispersion of beliefs has a significant and positive impact on trading volume, realized volatility, and returns; this is true for CPI, GDP and the unemployment rate with the dispersion for the unemployment rate again having the greatest magnitude of effect. Such results are consistent with the work by Banergee (2007), and Sarkar and Schwartz (2009), whereby a wider dispersion of beliefs increases both trading volume and return volatility.

Results for the recession period are generally similar, with two key differences noted. First, GDP news appears to be more important since stronger than expected (positive) GDP news is now significant for all three dependent variables, even when analyst dispersion is considered. Second, contrary to existing literature on other markets the reaction to news is of a lower magnitude during recession than at other times; the one exception is positive unemployment news which has much greater influence during the recession period.

\subsection{Conditional effects - GARCH Framework}

An alternative to modelling the impact of macroeconomic news on the gold futures market using ordinary least squares regression is to place the market and macroeconomic news factors into a GARCH framework where the dependent variables are volume and returns, this allows for the consideration of second-order effects; the results are reported in Table 4.

\section{$<$ Insert Table 4>}

The importance of unemployment news and dispersion of beliefs is re-emphasized; both unemployment and GDP news (good and bad) have a significant impact on the conditional mean of volume and returns, while belief dispersion for the two variables also induces a significant 
increase in market activity. Returns are confirmed to be generally positive (negative) in response to worse (better) than expected news.

Considering the conditional variance estimation provided in Panel $\mathrm{B}$, the ARCH and GARCH terms are significant in both markets, indicating the importance of observed volatility and forecasted variance in lagged periods; the sum of terms is higher for returns $(0.734)$ than for volume (0.598) indicating a greater persistence of volatility. Dispersion of analyst estimates for CPI and the unemployment rate significantly increases the volatility of traded volume, while the belief dispersion for all macroeconomic variables increases the conditional variance of market returns.

In summary, the empirical results demonstrate the importance of unemployment rate news, and to a lesser extent CPI and GDP news, in determining market activity. Consistent with the extant literature on dispersion of beliefs in equity markets, the results show that a wider dispersion of beliefs, as defined by the standard deviation of analyst forecasts, results in significant increases to trading volume, realized volatility, and market returns. This increased reaction is likely a result of a wider number of market participants needing to rebalance their portfolios in light of news. Contrary to prior work, the response of market activity seems to be stronger in the presence of good (rather than bad) news and recession does not induce an increase in the response. This result may be explained by the thought that investors hold gold for alternative reasons to traditional asset classes (e.g. stocks and bonds) such as the "safe-haven" rationale of Baur and Lucey (2010).

\section{Robustness Tests}

This section presents robustness tests for the empirical evidence reported in Section 3. Consistent with the concept of market efficiency, and more recent literature, the analysis has considered only the news component of macroeconomic announcements. However, it may be that in the case of commodity markets it is the presence of a news announcement that impacts the market and not the news component. In order to test the importance of the specification of the news event we repeat the earlier analysis of eq. (2) replacing the news variable with a dummy indicating whether the particular macroeconomic announcement occurred (1) or not (0). The results are reported in Table 5, and are qualitatively similar to those reported earlier. For instance, the coefficient for the unemployment news dummy has the largest magnitude, and has a 
significant impact on all dependent variables. All news dummies have a significant positive impact on volume but only when belief dispersion is incorporated into the analysis, while CPI and GDP have a significant impact on returns. The dispersion of beliefs on the unemployment rate has a significant impact on volume, volatility, and returns.

\section{$<$ Insert Table 5>}

The results reported in Section 3 suggest that, contrary to the extant literature, market reaction to news is less aggressive in recession than in other economic states; it is possible that this result is a result of categorizing the economic state on the basis of NBER recession classification. We perform a robustness test on this result by introducing economic states determined using the ICRG economic risk rating'; where the low performing economic period (recession) is indicated by an ICRG economic risk rating below 35 and a high performing period (expansion) is indicated by a risk rating above $38.5^{10}$. The results, reported in Table 6 , are consistent with those reported earlier. The magnitude of coefficients is generally smaller when the economy is performing less well (apart from the case of unemployment) than when it is performing strongly. Unemployment news, negative PPI news and positive GDP news all induce significant market responses in both low and high performing economic periods. Importantly, the reported coefficients for dispersion of beliefs for GDP and unemployment are positive and significant when the economy is performing poorly (i.e. wider dispersion of beliefs induces stronger market response to the announcement), while only GDP dispersion is important when the economy is performing well.

$<$ Insert Table 6>

\section{Conclusion}

Motivated by the increasingly widespread use of gold in investment portfolios, this paper seeks to answer a number of questions relating to the influence of macroeconomic news in determining levels of market activity such as trading volume, market returns, and realized volatility. By considering 10-second (30-second) intervals in the 12-minute (1-hour) period around the release of U.S. macroeconomic announcements, for the period November 2006 -

\footnotetext{
${ }^{9}$ The ICRG economic risk rating combines a number of economic indicators to provide a means of assessing a countries economic strength; a lower (higher) risk rating implies a higher (lower) economic risk or equivalently a lower (higher) performing economy. Detailed information on the methodology can be found at www.prsgroup.com

${ }^{10}$ Having divided the sample period into quintiles we find that the lowest quintile is the period when the economic risk weighting is below 35 , and the highest quintile is the period when the risk rating is above 38.5 .
} 
December 2012, we are able to draw a number of conclusions that will allow investors to understand, identify, and prepare for the instances in which changes in market activity will be extreme.

Our results demonstrate that macroeconomic news plays an important role in the trading volume, realized volatility, and return distribution of gold futures, with the major response occurring immediately following the announcement and subsiding almost entirely within the following 90-seconds; this result highlights the importance of using high-frequency data at appropriate intervals to consider such relationships. Gold futures tend to react positively to unexpectedly bad news, and positively to announcements reflecting an unexpected improvement in the economy.

There is evidence that news relating to the unemployment rate has the greatest effect on market activity, and contrary to the stock market literature the impact on market activity is found to be stronger in the presence of good (rather than bad) news and weaker during recession. This paper is the first to consider the importance of belief dispersion around macroeconomic news events, in this setting, and we provide strong evidence that belief dispersion plays a significant role in determining the market response to such news. Further work could consider other asset classes or alternative proxies for belief dispersion such as implied volatility; in addition it would be of interest to consider trading strategies that may be of use in situations where volatility and returns are expected to jump.

\section{References}

Andersen, T.G., T. Bollerslev, F.X. Diebold, and C. Vega, 2003, Micro effects of macro announcements: Real-time price discovery in foreign exchange, American Economic Review, 93, 38-62

Balduzzi, P., E.J. Elton, and T.C. Green, 2001, Economic news and bond prices: Evidence from the U.S. Treasury Market, Journal of Financial and Quantitative Analysis, 36, 523-543

Banergee, S., 2007, Learning from prices and the dispersion in beliefs, Stanford University Working Paper

Baur, D.G., and B.M. Lucey, 2010, Is gold a hedge or a safe haven? An analysis of stocks, bonds and gold, The Financial Review, 45, 217-229

Baur, D.G., and T.K. McDermott, 2010, Is gold a safe haven? International evidence, Journal of Banking \& Finance, 34, 1886-1898 
Becker, K., J. Finnerty, and K. Kopecky, 1996, Macroeconomic news and the efficiency of international bond futures markets, Journal of Futures Markets, 16, 131-145

Bildersee, J., S. Radhakrishnan, and J. Ronen, 1996, Dispersion of analysts' forecasts, precision of earnings, and trading volume reaction, International Review of Financial Analysis, 5, 99-111

Bollersley, T., 1986, Generalized Autoregressive Conditional Heteroskedasticity, Journal of Econometrics, 31, 307-327

Brenner, M., P. Pasquariello, and M. Subrahmanyam, 2009, On the volatility and comovement of U.S. financial markets around macroeconomic announcements, Journal of Financial and Quantitative Analysis, 44, 1265-1289

Cai, J., Y-L. Cheung, and M.C.S. Wong, 2001, What moves the gold market? Journal of Futures Markets, 21, 257-278

Capie. F., T.C. Mills, and G. Wood, 2005, Gold as a hedge against the dollar, Journal of International Financial Markets, Institutions and Money, 15 (4), 343-352

Chen, L.H., G.J. Jiang, and Q. Wang, 2013, Market reaction to information shocks: Does the Bloomberg and Briefing.com survey matter? Journal of Futures Markets, 16, 939-964

Christie-David, R., M. Chaudry, and T.W. Koch, 2000, Do macroeconomic news releases affect gold and silver prices? Journal of Economics and Business, 52, 405-421

Cook, T., and S. Korn, 1991, The reaction of interest rates to the employment report: The role of policy anticipations, Federal Reserve Bank of Richmond Economic Review, Fall, 3-12

Draper, P., D. Hillier, and R. Faff, 2006, Do precious metals shine? An investment perspective, Financial Analysts Journal, 62 (2), 98-106

Ederington, L., and J. Lee, 1993, How markets process information: News releases and volatility, Journal of Finance, 48, 1161-1191

Ederington, L., and J. Lee, 1995, The short-run dynamics of the price adjustment to new information, Journal of Financial and Quantitative Analysis, 30, 117-134

Ehrmann, M., and M. Fratzscher, 2005, Exchange rates and fundamentals: New evidence from real-time data, Journal of International Money and Finance, 24, 317-341

Elder, J., H. Miao, and S. Ramchander, 2012, Impact of macroeconomic news on metal futures, Journal of Banking \& Finance, 36, 51-65 
Engle, R.F., 1982, Autoregressive Conditional Heteroscedasticity with Estimates of the Variance of United Kingdom Inflation, Econometrica, 50, 987-1007

Fatum, R., and B. Scholnick, 2008, Monetary policy news and exchange rate responses: Do only surprises matter? Journal of Banking \& Finance, 32, 1076-1086

Flannery, M.J., and A.A. Protopapadakis, 2002, Macroeconomic factors do influence aggregate stock returns, Review of Financial Studies, 15, 751-782

Fleming, M.J., and M.E. Remolona, 1999, Price formation and liquidity in the U.S. Treasury Market: The response to public information, Journal of Finance, 54, 1901-1915

Frankel, J.A., 2008, The effect of monetary policy on real commodity prices, Asset prices and monetary policy, 291-327, University of Chicago Press.

Galati, G., and C. Ho, 2003, Macroeconomic news and the euro/dollar exchange rate, Economic Notes, 32, 371-398

Harris, M., and A. Raviv, 1993, Differences of opinion make a horse race, Review of Financial Studies, 6, 473-506

Hess, D., H. Huang, and A. Niessen, 2008, How do commodity futures respond to macroeconomic news? Financial Markets and Portfolio Management, 22, 127-146

Kandel, E.K., and N.D. Pearson, 1995, Differential interpretation of public signals and trade in speculative markets, Journal of Political Economy, 103, 831-872

Karpoff, J.M., 1986, A theory of trading volume, Journal of Finance, 41, 1069-1087

Kazemi, H.B., 1991, Dispersion of beliefs, asset prices, and noisy aggregation of information, Financial Review, 26, 1-13

Kim, S.-J., M.D. McKenzie, and R.W. Faff, 2004, Macroeconomic news announcements and the role of expectations: Evidence for U.S. bond, stock and foreign exchange markets, Journal of Multinational Financial Management, 14, 217-232

Kuttner, K., 2001, Monetary policy surprises and interest rates: Evidence from the Fed funds futures market, Journal of Monetary Economics, 47, 523-544

Li, D., and G. Li, 2013, Belief dispersion among household investors and stock trading volume, FRB Working Paper 
McCown, J.R., and J.R. Zimmerman, 2006, Is gold a zero-beta asset? Analysis of the investment potential of precious metals, Working Paper

McQueen, G., and V. Roley, 1993, Stock prices, news, and business conditions, Review of Financial Studies, 6, 683-707

Nikkinen, J., M. Omran, P. Sahlström, and J. Äijö, 2006, Global stock market reactions to scheduled U.S. macroeconomic news announcements, Global Finance Journal, 17, 92-104

Nikkinen, J, and P. Sahlström, 2004, Impact of the federal open market committee's meetings and scheduled macroeconomic news on stock market uncertainty, International Review of Financial Analysis, 13, 1-12

Rees, L., and W. Thomas, 2010, The stock price effects of changes in dispersion of investor beliefs during earnings announcements, Review of Accounting Studies, 15, 1-31

Riordan, R., A. Storkenmaier, M. Wagener, and S.S. Zhang, 2013, Public information arrival: Price discovery and liquidity in electronic order markets, Journal of Banking \& Finance, 37, 11481159

Roache, S.K., and M. Rossi, 2010, The effects of economic news on commodity prices, Quarterly Review of Economics and Finance, 50, 377-385

Roley, V., and G. Sellon, 1995, Monetary policy actions and long-term interest rates, Economic Quarterly, 80, 73-89

Sarkar, A., and R.A. Schwartz, 2009, Market sidedness: Insights into motives for trade initiation, Journal of Finance, 64, 375-423

Shalen, C.T., 1993, Volume, volatility, and the dispersion of beliefs, Review of Financial Studies, $6,405-434$

Smales, L.A., 2013, Impact of macroeconomic announcements on interest rate futures: Highfrequency evidence from Australia, Journal of Financial Research, 36, 371-388

Smales, L.A., 2014a, Asymmetric volatility response to news sentiment in gold futures, Working Paper

Smales, L.A., 2014b, News sentiment in the gold futures market, Working paper

Varian, H.R., 1985, Divergence of opinion in complete markets: A note, Journal of Finance, 40, 309-417 
Table 1

Summary Statistics

\begin{tabular}{|c|c|c|c|c|c|c|c|c|c|c|}
\hline \multirow{2}{*}{ Panel A: Gold Futures } & \multirow[b]{2}{*}{ Mean } & \multirow[b]{2}{*}{ SD } & \multirow[b]{2}{*}{ Skewness } & \multirow[b]{2}{*}{ Kurtosis } & \multirow[b]{2}{*}{ Jarque-Bera } & \multicolumn{4}{|c|}{ Partial Autocorrelation at Lag: } & \multirow{2}{*}{$\begin{array}{c}\text { Unit Root } \\
\text { Test Statistic }\end{array}$} \\
\hline & & & & & & 1 & 2 & 3 & 4 & \\
\hline \multicolumn{11}{|l|}{ 10-second intervals } \\
\hline Return & 0.00004 & 0.039 & -0.710 & 226.85 & 230 & 0.080 & -0.014 & -0.004 & -0.002 & $-97.53^{*}$ \\
\hline Volatility & 0.145 & 0.466 & 15.685 & 333.22 & 502 & 0.337 & 0.335 & 0.150 & 0.130 & $-14.51^{*}$ \\
\hline Volume & 20.925 & 58.243 & 12.192 & 347.79 & 546 & 0.571 & 0.257 & 0.182 & 0.084 & $-27.83^{*}$ \\
\hline \multicolumn{11}{|l|}{ 30-second intervals } \\
\hline Return & 0.0005 & 0.118 & 2.203 & 1099.85 & 919 & 0.021 & -0.003 & 0.001 & 0.000 & $-419.37^{*}$ \\
\hline Volatility & 0.212 & 0.477 & 11.470 & 181.17 & 246 & 0.605 & 0.312 & 0.215 & 0.192 & $-16.34^{*}$ \\
\hline Volume & 54.477 & 125.644 & 10.853 & 382.82 & 111 & 0.622 & 0.230 & 0.137 & 0.086 & $-24.13^{*}$ \\
\hline
\end{tabular}

\begin{tabular}{|c|c|c|c|c|c|c|c|c|}
\hline \multicolumn{9}{|c|}{ Panel B: Macroeconomic News } \\
\hline & $\mathrm{N}$ & $\begin{array}{c}\text { Mean } \\
\text { Dispersion }\end{array}$ & Mean News & $\begin{array}{l}\text { Std. Dev. } \\
\text { Of News }\end{array}$ & Min. News & Max. News & $\begin{array}{c}\text { Time of } \\
\text { announcement }\end{array}$ & $\begin{array}{l}\text { Frequency of } \\
\text { release }\end{array}$ \\
\hline Consumer Price Index & 73 & 0.130 & 0.000 & 0.992 & -2.866 & 2.866 & 8:30 AM & Monthly \\
\hline Gross Domestic Product & 24 & 0.133 & 0.051 & 0.914 & -2.124 & 2.580 & 8:30 AM & Quarterly \\
\hline Personal Income & 74 & 0.151 & 0.174 & 1.083 & -1.736 & 5.209 & 8:30 AM & Monthly \\
\hline Producer Price Index & 73 & 0.301 & 0.164 & 0.999 & -2.320 & 3.286 & 8:30 AM & Monthly \\
\hline Unemployment Rate & 73 & 0.093 & -0.143 & 1.154 & -3.267 & 2.613 & 8:30 AM & Monthly \\
\hline
\end{tabular}

This table presents summary data for the variables utilised in this study, using intraday observations around macroeconomic announcements for the period 24 November 2006 - 31 December 2012. The specific period for 10-second intervals runs from 2-minutes prior to the announcement to 10-minutes after, while the period for 30-

second intervals runs from 15-minutes prior to the announcement to 45-minutes post-announcement. Panel A contains statistics relevant to the return, volatility and volume of gold futures. Unit root tests are conducted using Augmented Dickey Fuller with trend and intercept; * indicates rejection of the null of a unit root. Panel B provides information on the macroeconomic announcements considered in the study, with dispersion indicating the standard deviation of analyst forecasts for the given announcement and news indicating the standardised surprise component of the given data release. 
Table 2

Baseline Regression: Relationship between market activity and macroeconomic news

\begin{tabular}{|c|c|c|c|c|c|c|c|c|c|c|c|c|}
\hline \multirow[t]{2}{*}{ Dependent Variable: } & \multicolumn{4}{|c|}{ Log(Volume) } & \multicolumn{4}{|c|}{ Volatility } & \multicolumn{4}{|c|}{ Returns } \\
\hline & (1) & & (2) & & (3) & & (4) & & (5) & & (6) & \\
\hline \multirow[t]{2}{*}{ Constant } & 1.320 & **** & 1.315 & **** & 0.096 & **** & 0.096 & **** & 0.002 & & 0.002 & \\
\hline & $(0.018)$ & & $(0.016)$ & & $(0.005)$ & & $(0.004)$ & & $(0.002)$ & & $(0.002)$ & \\
\hline \multirow[t]{2}{*}{ CPI_News } & 0.224 & & 0.165 & & 0.044 & & 0.053 & & 0.001 & & 0.002 & \\
\hline & $(0.302)$ & & $(0.203)$ & & $(0.049)$ & & $(0.050)$ & & $(0.006)$ & & $(0.004)$ & \\
\hline \multirow[t]{2}{*}{ GDP_News } & 0.201 & & 0.039 & & 0.069 & & 0.055 & & 0.008 & & 0.007 & \\
\hline & $(0.268)$ & & $(0.143)$ & & $(0.062)$ & & $(0.035)$ & & $(0.018)$ & & $(0.016)$ & \\
\hline \multirow[t]{2}{*}{ PINC_News } & 0.094 & & 0.147 & & 0.009 & & 0.014 & & 0.002 & & 0.001 & \\
\hline & $(0.333)$ & & $(0.122)$ & & $(0.013)$ & & $(0.019)$ & & $(0.002)$ & & $(0.003)$ & \\
\hline \multirow[t]{2}{*}{ PPI_News } & 0.345 & & 0.163 & & 0.130 & & 0.116 & & 0.007 & * & 0.005 & \\
\hline & $(0.325)$ & & $(0.231)$ & & $(0.135)$ & & $(0.135)$ & & $(0.003)$ & & $(0.003)$ & \\
\hline \multirow[t]{2}{*}{ UNEMP_News } & 0.274 & $* * *$ & 0.094 & & 0.220 & $* *$ & 0.188 & & 0.023 & & 0.017 & \\
\hline & $(0.102)$ & & $(0.062)$ & & $(0.106)$ & & $(0.122)$ & & $(0.016)$ & & $(0.010)$ & \\
\hline \multirow[t]{2}{*}{ CPI_Dispersion } & & & 6.173 & $* * *$ & & & 0.882 & $* * *$ & & & 0.116 & $* *$ \\
\hline & & & (1.039) & & & & $(0.319)$ & & & & $(0.048)$ & \\
\hline \multirow[t]{2}{*}{ GDP_Dispersion } & & & 8.480 & $* * *$ & & & 1.754 & $* * *$ & & & 0.141 & $* *$ \\
\hline & & & $(1.366)$ & & & & $(0.378)$ & & & & $(0.067)$ & \\
\hline \multirow[t]{2}{*}{ PINC_Dispersion } & & & 1.877 & $* *$ & & & 0.093 & & & & -0.013 & \\
\hline & & & $(0.829)$ & & & & $(0.109)$ & & & & $(0.021)$ & \\
\hline \multirow[t]{2}{*}{ PPI_Dispersion } & & & 1.820 & $* * *$ & & & 0.173 & & & & 0.018 & * \\
\hline & & & $(0.442)$ & & & & $(0.111)$ & & & & $(0.009)$ & \\
\hline \multirow[t]{2}{*}{ UNEMP_Dispersion } & & & 23.448 & $* * *$ & & & 6.035 & $* * *$ & & & 1.135 & *** \\
\hline & & & $(1.237)$ & & & & $(1.083)$ & & & & $(0.171)$ & \\
\hline \multirow[t]{2}{*}{ Lagged_Dependent } & 0.576 & $* * *$ & 0.577 & $* * *$ & 0.337 & $* * *$ & 0.337 & $* * *$ & 0.117 & $* * *$ & 0.116 & $* * *$ \\
\hline & $(0.007)$ & & $(0.006)$ & & $(0.029)$ & & $(0.029)$ & & $(0.007)$ & & $(0.007)$ & \\
\hline Adj. $R^{2}$ & 0.326 & & 0.334 & & 0.114 & & 0.115 & & 0.014 & & 0.021 & \\
\hline F-Statistic & 7583.4 & & 1837.2 & & 2011.8 & & 1096.9 & & 222.2 & & 183.5 & \\
\hline AIC & 10.572 & & 2.949 & & 2.189 & & 2.189 & & 3.879 & & 3.886 & \\
\hline Durbin Watson Statistic & 2.293 & & 2.304 & & 2.226 & & 2.227 & & 2.016 & & 2.025 & \\
\hline
\end{tabular}

This table presents regression results from the baseline regression specificied in equation (2). The dependent variables are the natural logarithm of volume traded $(\log ($ volume $))$, realized volatility of returns, and market returns. News or surprise components of announcements for the consumer price index $(C P I)$, gross domestic product $(G D P)$, personal income $(P I N C)$, producer price index $(P P I)$, and the unemployment rate $(U N E M P)$ are considered as explanatory variables. In addition, measures of belief dispersion around the announcement, determined as the standard deviation of analyst estimates, are incorporated into models 2, 4, and 6. Newey-West standard errors are shown in parantheses, where the appropriate number of lags in each case is determined using Akaike Information Criterion (AIC).

${ }^{* * *},{ }^{* *}$, and ${ }^{*}$ denote significance at the $1, \%, 5 \%$, and $10 \%$ levels respectively. 
Table 3

Regression: Relationship between market activity and disaggregated macroeconomic news

\begin{tabular}{|c|c|c|c|c|c|c|c|c|c|c|c|c|c|c|c|c|c|c|c|c|c|c|c|c|}
\hline \multirow{3}{*}{ Dependent Variable: } & \multicolumn{12}{|c|}{ Whole Sample } & \multicolumn{12}{|c|}{ Recession } \\
\hline & \multicolumn{4}{|c|}{ Log(Volume) } & \multicolumn{4}{|c|}{ Volatility } & \multicolumn{4}{|c|}{ Returns } & \multicolumn{4}{|c|}{ Log(Volume) } & \multicolumn{4}{|c|}{ Volatility } & \multicolumn{4}{|c|}{ Returns } \\
\hline & (1) & & (2) & & (3) & & (4) & & (5) & & (6) & & (7) & & (8) & & (9) & & (10) & & $(11)$ & & (12) & \\
\hline Constant & $\begin{array}{c}1.313 \\
(0.459)\end{array}$ & $* * *$ & $\begin{array}{c}1.315 \\
(0.018)\end{array}$ & $* * *$ & $\begin{array}{c}0.096 \\
(0.005)\end{array}$ & $* * *$ & $\begin{array}{c}0.096 \\
(0.005)\end{array}$ & *** & $\begin{array}{c}0.002 \\
(0.002)\end{array}$ & & $\begin{array}{c}0.002 \\
(0.002)\end{array}$ & & $\begin{array}{c}1.458 \\
(0.032)\end{array}$ & $* * *$ & $\begin{array}{c}1.459 \\
(0.032)\end{array}$ & *** & $\begin{array}{c}0.058 \\
(0.001)\end{array}$ & *** & $\begin{array}{c}0.058 \\
(0.001)\end{array}$ & & $\begin{array}{c}0.002 \\
(0.004)\end{array}$ & & $\begin{array}{c}0.002 \\
(0.004)\end{array}$ & \\
\hline /Neg_CPI_News/ & $\begin{array}{c}0.735 \\
(8.013)\end{array}$ & & $\begin{array}{c}0.088 \\
(0.382)\end{array}$ & & $\begin{array}{c}0.077 \\
(0.036)\end{array}$ & $* *$ & $\begin{array}{c}0.022 \\
(0.070)\end{array}$ & & $\begin{array}{c}0.014 \\
(0.009)\end{array}$ & & $\begin{array}{c}0.004 \\
(0.009)\end{array}$ & & $\begin{array}{c}0.469 \\
(0.272)\end{array}$ & $*$ & $\begin{array}{c}0.093 \\
(0.267)\end{array}$ & & $\begin{array}{c}0.042 \\
(0.018)\end{array}$ & ** & $\begin{array}{c}0.011 \\
(0.033)\end{array}$ & & $\begin{array}{c}0.003 \\
(0.004)\end{array}$ & & $\begin{array}{c}0.001 \\
(0.006)\end{array}$ & \\
\hline |Neg_GDP_News/ & $\begin{array}{c}1.170 \\
(20.905)\end{array}$ & $* * *$ & $\begin{array}{c}0.279 \\
(0.282)\end{array}$ & & $\begin{array}{c}0.154 \\
(0.072)\end{array}$ & ${ }^{* *}$ & $\begin{array}{c}0.027 \\
(0.064)\end{array}$ & & $\begin{array}{c}0.033 \\
(0.028)\end{array}$ & & $\begin{array}{c}0.029 \\
(0.029)\end{array}$ & & $\begin{array}{c}0.668 \\
(0.121)\end{array}$ & $* * *$ & $\begin{array}{c}0.656 \\
(0.118)\end{array}$ & $* * *$ & $\begin{array}{c}0.179 \\
(0.101)\end{array}$ & * & $\begin{array}{c}0.127 \\
(0.092)\end{array}$ & & $\begin{array}{c}0.037 \\
(0.040)\end{array}$ & & $\begin{array}{c}0.018 \\
(0.036)\end{array}$ & \\
\hline /Neg_PINC_News/ & $\begin{array}{c}0.928 \\
(4.807)\end{array}$ & & $\begin{array}{c}0.899 \\
(0.638)\end{array}$ & & $\begin{array}{c}0.039 \\
(0.045)\end{array}$ & & $\begin{array}{c}0.031 \\
(0.055)\end{array}$ & & $\begin{array}{c}0.018 \\
(0.012)\end{array}$ & & $\begin{array}{c}0.007 \\
(0.009)\end{array}$ & & $\begin{array}{c}2.039 \\
(0.329)\end{array}$ & $* * *$ & $\begin{array}{c}0.070 \\
(0.676)\end{array}$ & & $\begin{array}{c}0.083 \\
(0.038)\end{array}$ & ** & $\begin{array}{c}0.065 \\
(0.042)\end{array}$ & & $\begin{array}{c}0.011 \\
(0.013)\end{array}$ & & $\begin{array}{c}0.016 \\
(0.012)\end{array}$ & \\
\hline |Neg_PPI_News/ & $\begin{array}{c}1.377 \\
(11.400)\end{array}$ & $*$ & $\begin{array}{c}1.251 \\
(0.525)\end{array}$ & ${ }^{* *}$ & $\begin{array}{c}0.104 \\
(0.059)\end{array}$ & * & $\begin{array}{c}0.170 \\
(0.121)\end{array}$ & & $\begin{array}{c}0.005 \\
(0.005)\end{array}$ & & $\begin{array}{c}0.004 \\
(0.006)\end{array}$ & & $\begin{array}{c}0.638 \\
(0.449)\end{array}$ & & $\begin{array}{c}0.383 \\
(0.604)\end{array}$ & & $\begin{array}{c}0.052 \\
(0.036)\end{array}$ & & $\begin{array}{c}0.024 \\
(0.043)\end{array}$ & & $\begin{array}{c}0.001 \\
(0.006)\end{array}$ & & $\begin{array}{c}0.005 \\
(0.014)\end{array}$ & \\
\hline |Neg_UNEMP_News/ & $\begin{array}{c}1.210 \\
(28.883)\end{array}$ & ${ }^{* *}$ & $\begin{array}{c}0.540 \\
(0.262)\end{array}$ & ${ }^{* *}$ & $\begin{array}{c}0.351 \\
(0.069)\end{array}$ & $* * *$ & $\begin{array}{c}0.035 \\
(0.102)\end{array}$ & & $\begin{array}{l}-0.074 \\
(0.015)\end{array}$ & $* * *$ & $\begin{array}{c}0.005 \\
(0.018)\end{array}$ & & $\begin{array}{c}1.067 \\
(0.502)\end{array}$ & $* *$ & $\begin{array}{c}0.485 \\
(0.539)\end{array}$ & & $\begin{array}{c}0.312 \\
(0.069)\end{array}$ & $* *$ & $\begin{array}{c}0.056 \\
(0.066)\end{array}$ & & $\begin{array}{l}-0.057 \\
(0.015)\end{array}$ & $* * *$ & $\begin{array}{c}0.006 \\
(0.021)\end{array}$ & \\
\hline Pos_CPI_News & $\begin{array}{c}0.762 \\
(11.682)\end{array}$ & $*$ & $\begin{array}{c}0.271 \\
(0.489)\end{array}$ & & $\begin{array}{c}0.151 \\
(0.086)\end{array}$ & * & $\begin{array}{c}0.087 \\
(0.087)\end{array}$ & & $\begin{array}{l}-0.015 \\
(0.005)\end{array}$ & $* * *$ & $\begin{array}{l}-0.008 \\
(0.009)\end{array}$ & & $\begin{array}{c}0.259 \\
(0.265)\end{array}$ & & $\begin{array}{c}0.239 \\
(0.135)\end{array}$ & * & $\begin{array}{c}0.044 \\
(0.021)\end{array}$ & ** & $\begin{array}{c}0.021 \\
(0.019)\end{array}$ & & $\begin{array}{l}-0.008 \\
(0.006)\end{array}$ & & $\begin{array}{l}-0.009 \\
(0.006)\end{array}$ & \\
\hline Pos_GDP_News & $\begin{array}{c}2.486 \\
(28.148)\end{array}$ & & $\begin{array}{c}0.776 \\
(0.425)\end{array}$ & * & $\begin{array}{c}0.213 \\
(0.041)\end{array}$ & $* * *$ & $\begin{array}{c}0.074 \\
(0.046)\end{array}$ & & $\begin{array}{l}-0.034 \\
(0.013)\end{array}$ & $* * *$ & $\begin{array}{l}-0.032 \\
(0.015)\end{array}$ & $* *$ & $\begin{array}{c}1.237 \\
(0.042)\end{array}$ & $* * *$ & $\begin{array}{c}1.214 \\
(0.093)\end{array}$ & $* * *$ & $\begin{array}{c}0.180 \\
(0.026)\end{array}$ & $* * *$ & $\begin{array}{c}0.135 \\
(0.059)\end{array}$ & $* *$ & $\begin{array}{l}-0.042 \\
(0.009)\end{array}$ & $* * *$ & $\begin{array}{l}-0.026 \\
(0.018)\end{array}$ & \\
\hline Pos_PINC_News & $\begin{array}{c}0.391 \\
(4.171)\end{array}$ & ${ }^{*}$ & $\begin{array}{c}0.372 \\
(0.222)\end{array}$ & * & $\begin{array}{c}0.020 \\
(0.011)\end{array}$ & * & $\begin{array}{c}0.002 \\
(0.014)\end{array}$ & & $\begin{array}{l}-0.002 \\
(0.001)\end{array}$ & & $\begin{array}{l}-0.001 \\
(0.002)\end{array}$ & & $\begin{array}{c}0.350 \\
(0.152)\end{array}$ & $* *$ & $\begin{array}{c}0.539 \\
(0.175)\end{array}$ & $* * *$ & $\begin{array}{c}0.037 \\
(0.014)\end{array}$ & $* *$ & $\begin{array}{c}0.024 \\
(0.016)\end{array}$ & & $\begin{array}{l}-0.001 \\
(0.002)\end{array}$ & & $\begin{array}{l}-0.004 \\
(0.003)\end{array}$ & \\
\hline Pos_PPI_News & $\begin{array}{c}1.564 \\
(5.377)\end{array}$ & & $\begin{array}{c}1.473 \\
(0.272)\end{array}$ & $* * *$ & $\begin{array}{c}0.240 \\
(0.204)\end{array}$ & & $\begin{array}{c}0.298 \\
(0.283)\end{array}$ & & $\begin{array}{l}-0.012 \\
(0.004)\end{array}$ & $* * *$ & $\begin{array}{l}-0.012 \\
(0.007)\end{array}$ & * & $\begin{array}{c}1.133 \\
(0.283)\end{array}$ & $* * *$ & $\begin{array}{c}0.848 \\
(0.399)\end{array}$ & $* *$ & $\begin{array}{c}0.030 \\
(0.005)\end{array}$ & $* *$ & $\begin{array}{c}0.017 \\
(0.026)\end{array}$ & & $\begin{array}{l}-0.001 \\
(0.003)\end{array}$ & & $\begin{array}{l}-0.003 \\
(0.009)\end{array}$ & \\
\hline Pos_UNEMP_News & $\begin{array}{c}1.640 \\
(40.547)\end{array}$ & $* *$ & $\begin{array}{c}0.435 \\
(0.312)\end{array}$ & & $\begin{array}{c}0.594 \\
(0.199)\end{array}$ & $* * *$ & $\begin{array}{c}0.347 \\
(0.231)\end{array}$ & & $\begin{array}{c}0.087 \\
(0.017)\end{array}$ & $* * *$ & $\begin{array}{l}-0.033 \\
(0.018)\end{array}$ & * & $\begin{array}{c}3.431 \\
(1.092)\end{array}$ & $* * *$ & $\begin{array}{c}4.044 \\
(1.125)\end{array}$ & $* * *$ & $\begin{array}{c}0.627 \\
(0.075)\end{array}$ & $* * *$ & $\begin{array}{c}0.212 \\
(0.125)\end{array}$ & & $\begin{array}{c}0.107 \\
(0.029)\end{array}$ & $* * *$ & $\begin{array}{l}-0.005 \\
(0.038)\end{array}$ & \\
\hline CPI_Dispersion & & & $\begin{array}{c}5.964 \\
(2.202)\end{array}$ & $* * *$ & & & $\begin{array}{c}0.772 \\
(0.282)\end{array}$ & $* *$ & & & $\begin{array}{c}0.090 \\
(0.036)\end{array}$ & $* *$ & & & $\begin{array}{c}2.901 \\
(1.098)\end{array}$ & $* * *$ & & & $\begin{array}{c}0.327 \\
(0.269)\end{array}$ & & & & $\begin{array}{l}-0.020 \\
(0.043)\end{array}$ & \\
\hline GDP_Dispersion & & & $\begin{array}{c}9.664 \\
(3.169)\end{array}$ & $* * *$ & & & $\begin{array}{c}1.670 \\
(0.479)\end{array}$ & $* * *$ & & & $\begin{array}{c}0.033 \\
(0.016)\end{array}$ & $* *$ & & & $\begin{array}{c}0.191 \\
(0.802)\end{array}$ & & & & $\begin{array}{c}0.816 \\
(0.933)\end{array}$ & & & & $\begin{array}{c}0.296 \\
(0.261)\end{array}$ & \\
\hline PINC_Dispersion & & & $\begin{array}{c}0.208 \\
(2.102)\end{array}$ & & & & $\begin{array}{c}0.145 \\
(0.096)\end{array}$ & & & & $\begin{array}{l}-0.004 \\
(0.015)\end{array}$ & & & & $\begin{array}{c}2.123 \\
(0.941)\end{array}$ & $* *$ & & & $\begin{array}{c}0.118 \\
(0.163)\end{array}$ & & & & $\begin{array}{l}-0.031 \\
(0.017)\end{array}$ & * \\
\hline PPI_Dispersion & & & $\begin{array}{c}0.156 \\
(0.311)\end{array}$ & & & & $\begin{array}{c}0.229 \\
(0.313)\end{array}$ & & & & $\begin{array}{c}0.004 \\
(0.013)\end{array}$ & & & & $\begin{array}{c}0.497 \\
(0.967)\end{array}$ & & & & $\begin{array}{c}0.240 \\
(0.124)\end{array}$ & $*$ & & & $\begin{array}{c}0.021 \\
(0.043)\end{array}$ & \\
\hline UNEMP_Dispersion & & & $\begin{array}{l}27.767 \\
(3.687)\end{array}$ & $* * *$ & & & $\begin{array}{c}4.545 \\
(1.501)\end{array}$ & $* * *$ & & & $\begin{array}{c}0.985 \\
(0.229)\end{array}$ & $* * *$ & & & $\begin{array}{l}25.739 \\
(7.720)\end{array}$ & $* * *$ & & & $\begin{array}{c}4.258 \\
(1.161)\end{array}$ & $* * *$ & & & $\begin{array}{c}1.048 \\
(0.346)\end{array}$ & ${ }^{* * *}$ \\
\hline Lagged_Dependent & $\begin{array}{c}0.577 \\
(0.019)\end{array}$ & $* * *$ & $\begin{array}{c}0.577 \\
(0.006)\end{array}$ & $* * *$ & $\begin{array}{c}0.337 \\
(0.029)\end{array}$ & $* * *$ & $\begin{array}{c}0.337 \\
(0.029)\end{array}$ & $* * *$ & $\begin{array}{c}0.116 \\
(0.008)\end{array}$ & $* * *$ & $\begin{array}{c}0.116 \\
(0.008)\end{array}$ & $* * *$ & $\begin{array}{c}0.547 \\
(0.010)\end{array}$ & $* * *$ & $\begin{array}{c}0.547 \\
(0.009)\end{array}$ & $* * *$ & $\begin{array}{c}0.426 \\
0.01443\end{array}$ & $* * *$ & $\begin{array}{c}0.425 \\
(0.014)\end{array}$ & $* * *$ & $\begin{array}{c}0.097 \\
(0.011)\end{array}$ & $* * *$ & $\begin{array}{c}0.097 \\
(0.011)\end{array}$ & $* * *$ \\
\hline Adj. $\mathrm{R}^{2}$ & 0.333 & & 0.334 & & 0.115 & & 0.115 & & 0.019 & & 0.022 & & 0.303 & & 0.367 & & 0.196 & & 0.202 & & 0.012 & & 0.013 & \\
\hline F-Statistic & 1837.9 & & 1258.5 & & 1094.2 & & 751.6 & & 161.4 & & 127.0 & & 476.1 & & 968.9 & & 595.4 & & 422.7 & & 29.4 & & 22.6 & \\
\hline AIC & 2.952 & & 2.949 & & 1.188 & & 1.187 & & -3.884 & & -3.886 & & 2.853 & & 10.184 & & -2.159 & & -2.166 & & -3.381 & & -3.382 & \\
\hline Durbin Watson Statistic & 2.303 & & 2.305 & & 2.227 & & 2.227 & & 2.022 & & 2.025 & & 2.278 & & 2.311 & & 2.184 & & 2.187 & & 2.016 & & 2.019 & \\
\hline
\end{tabular}

This table presents regression results from the augmented version of the baseline regression specificied in equation (2). The dependent variables are the natural logarithm of volume traded (log(volume)), realized volatility of returns, and market returns. News or surprise components of announcements for the consumer price index $(C P I)$, gross domestic product $(G D P)$, personal income $(P I N C)$, producer price index $(P P I)$, and the unemployment rate $(U N E M P)$ are disaggregated into negative (neg) and positive (pos) components. In addition, measures of belief dispersion around the announcement, determined as the standard deviation of analyst estimates, are incorporated into models 2,4 , 6, 8, 10, \& 12. Estimates are provided for the whole sample period (Nov 2006 - Dec 2012), and for the period encorporating the NBER defined recession (Oct 2007 - June 2009 ). Newey-West standard errors are shown in parantheses, where the appropriate number of lags in each case is determined using Akaike Information Criterion (AIC).

${ }^{* * *},{ }^{* *}$, and ${ }^{*}$ denote significance at the $1, \%, 5 \%$, and $10 \%$ levels respectively. 
Table 4

Regression: Modelling the market activity - macroeconomic news relationship in a GARCH(1,1) framework

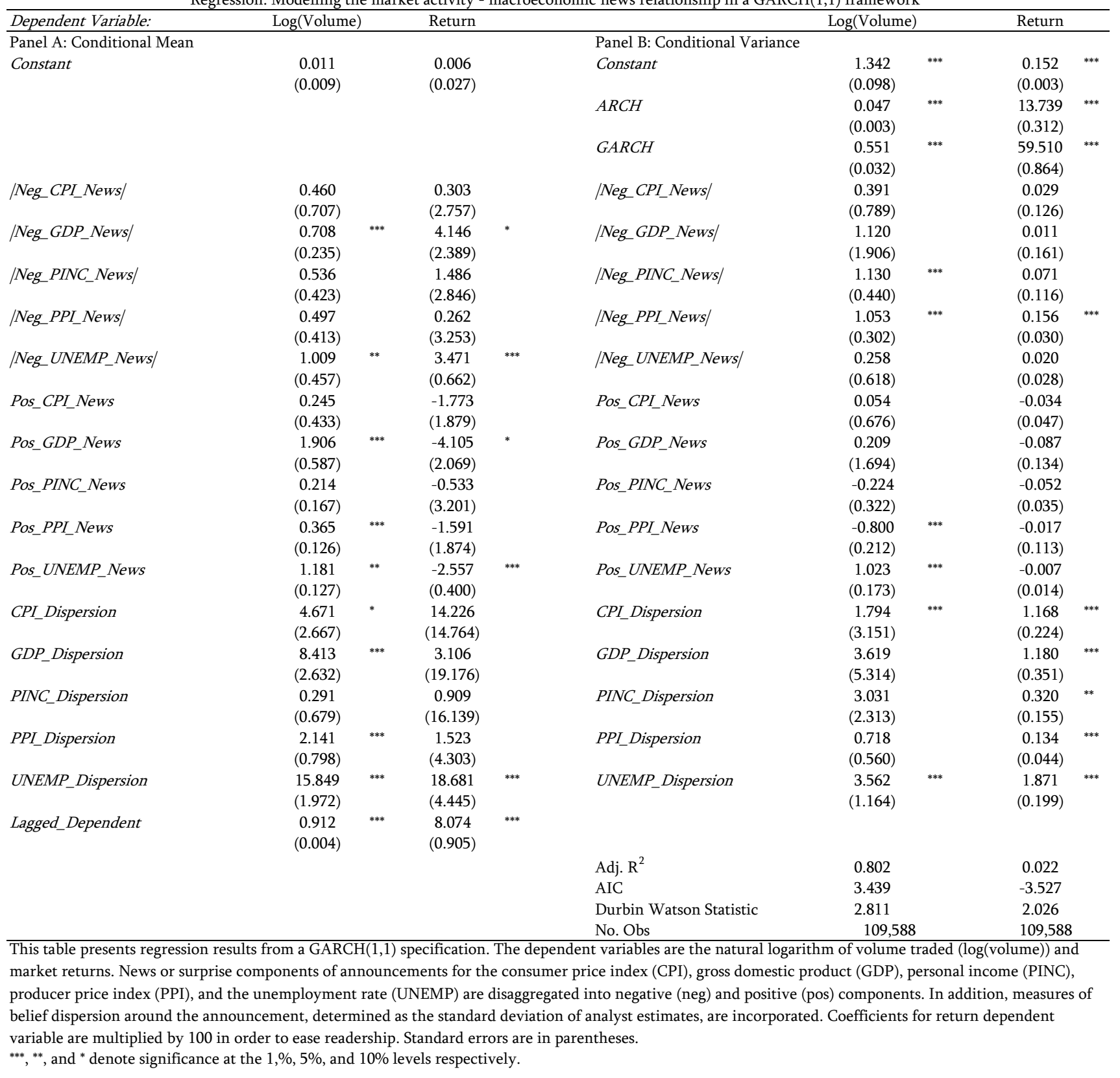


Table 5

Robustness Test: Consideration of macroeconomic release dummy

\begin{tabular}{|c|c|c|c|c|c|c|c|c|c|c|c|c|}
\hline Dependent Variable: & $\begin{array}{c}\log (\text { Volume }) \\
(1)\end{array}$ & & $\begin{array}{c}\text { og(Volum } \\
(2)\end{array}$ & & $\begin{array}{c}\text { Volatility } \\
(3) \\
\end{array}$ & & $\begin{array}{c}\text { Volatility } \\
(4)\end{array}$ & & $\begin{array}{c}\text { Returns } \\
\text { (5) }\end{array}$ & & $\begin{array}{c}\text { Returns } \\
(6) \\
\end{array}$ & \\
\hline Constant & $\begin{array}{c}1.314 \\
(0.445)\end{array}$ & $* * *$ & $\begin{array}{c}1.314 \\
(0.016)\end{array}$ & $* * *$ & $\begin{array}{c}0.095 \\
(0.005)\end{array}$ & *** & $\begin{array}{c}0.095 \\
(0.005)\end{array}$ & $* * *$ & $\begin{array}{c}0.002 \\
(0.002)\end{array}$ & & $\begin{array}{c}0.002 \\
(0.002)\end{array}$ & \\
\hline CPI_Dummy & $\begin{array}{c}1.126 \\
(15.980)\end{array}$ & & $\begin{array}{c}1.465 \\
(0.325)\end{array}$ & $* * *$ & $\begin{array}{c}0.146 \\
(0.068)\end{array}$ & $* *$ & $\begin{array}{c}0.201 \\
(0.118)\end{array}$ & * & $\begin{array}{c}0.011 \\
(0.003)\end{array}$ & $* * *$ & $\begin{array}{l}-0.012 \\
(0.015)\end{array}$ & \\
\hline GDP_Dummy & $\begin{array}{c}1.614 \\
(26.644)\end{array}$ & & $\begin{array}{c}1.881 \\
(0.549)\end{array}$ & $* * *$ & $\begin{array}{c}0.260 \\
(0.067)\end{array}$ & *** & $\begin{array}{c}0.160 \\
(0.174)\end{array}$ & & $\begin{array}{c}0.028 \\
(0.011)\end{array}$ & $* *$ & $\begin{array}{c}0.064 \\
(0.026)\end{array}$ & ** \\
\hline PINC_Dummy & $\begin{array}{c}0.693 \\
(6.164)\end{array}$ & & $\begin{array}{c}0.978 \\
(0.256)\end{array}$ & $* * *$ & $\begin{array}{c}0.017 \\
(0.024)\end{array}$ & & $\begin{array}{c}0.002 \\
(0.034)\end{array}$ & & $\begin{array}{c}0.003 \\
(0.004)\end{array}$ & & $\begin{array}{c}0.004 \\
(0.006)\end{array}$ & \\
\hline PPI_Dummy & $\begin{array}{c}1.225 \\
(5.461)\end{array}$ & & $\begin{array}{c}1.155 \\
(0.227)\end{array}$ & $* * *$ & $\begin{array}{c}0.200 \\
(0.124)\end{array}$ & & $\begin{array}{c}0.341 \\
(0.258)\end{array}$ & & $\begin{array}{c}0.008 \\
(0.003)\end{array}$ & $* *$ & $\begin{array}{c}0.006 \\
(0.003)\end{array}$ & $*$ \\
\hline UNEMP_Dummy & $\begin{array}{c}2.360 \\
(1.198)\end{array}$ & $* *$ & $\begin{array}{c}2.582 \\
(1.002)\end{array}$ & $* * *$ & $\begin{array}{c}0.718 \\
(0.098)\end{array}$ & $* * *$ & $\begin{array}{c}0.999 \\
(0.233)\end{array}$ & $* * *$ & $\begin{array}{c}0.127 \\
(0.014)\end{array}$ & $* * *$ & $\begin{array}{c}0.142 \\
(0.047)\end{array}$ & $* * *$ \\
\hline CPI_Dispersion & & & $\begin{array}{c}2.238 \\
(1.661)\end{array}$ & & & & $\begin{array}{c}0.407 \\
(0.446)\end{array}$ & & & & $\begin{array}{c}0.178 \\
(0.123)\end{array}$ & \\
\hline GDP_Dispersion & & & $\begin{array}{c}2.164 \\
(3.349)\end{array}$ & & & & $\begin{array}{c}0.750 \\
(1.019)\end{array}$ & & & & $\begin{array}{c}0.265 \\
(0.124)\end{array}$ & $* *$ \\
\hline PINC_Dispersion & & & $\begin{array}{c}2.085 \\
(1.125)\end{array}$ & * & & & $\begin{array}{c}0.107 \\
(0.096)\end{array}$ & & & & $\begin{array}{l}-0.005 \\
(0.016)\end{array}$ & \\
\hline PPI_Dispersion & & & $\begin{array}{c}0.259 \\
(0.495)\end{array}$ & & & & $\begin{array}{c}0.488 \\
(0.507)\end{array}$ & & & & $\begin{array}{c}0.006 \\
(0.007)\end{array}$ & \\
\hline UNEMP_Dispersion & & & $\begin{array}{c}2.358 \\
(1.098)\end{array}$ & $* *$ & & & $\begin{array}{c}3.011 \\
(1.143)\end{array}$ & $* * *$ & & & $\begin{array}{c}0.459 \\
(0.135)\end{array}$ & $* * *$ \\
\hline Lagged_Dependent & $\begin{array}{c}0.577 \\
(0.019)\end{array}$ & $* * *$ & $\begin{array}{c}0.577 \\
(0.006)\end{array}$ & $* * *$ & $\begin{array}{c}0.337 \\
(0.029)\end{array}$ & $* * *$ & $\begin{array}{c}0.337 \\
(0.029)\end{array}$ & $* * *$ & $\begin{array}{c}0.116 \\
(0.007)\end{array}$ & $* * *$ & $\begin{array}{c}0.116 \\
(0.007)\end{array}$ & $* * *$ \\
\hline Adj. R2 & 0.334 & & 0.335 & & 0.115 & & 0.116 & & 0.023 & & 0.023 & \\
\hline F-Statistic & 3422.0 & & 1842.8 & & 2044.6 & & 1102.4 & & 362.9 & & 196.7 & \\
\hline AIC & 2.949 & & 2.948 & & 2.187 & & 2.187 & & 3.888 & & 3.888 & \\
\hline Durbin Watson Statistic & 2.305 & & 2.306 & & 2.227 & & 2.227 & & 2.027 & & 2.027 & \\
\hline
\end{tabular}

This table presents regression results for a test of robustness. The dependent variables are the natural logarithm of volume traded (log(volume)), realized volatility of returns, and market returns. The explanatory variables are dummy variables indicating the releases of the consumer price index ( $C P I)$, gross domestic product $(G D P)$, personal income $(P I N C)$, producer price index $(P P I)$, and the unemployment rate $(U N E M P)$ rather than news components of those releases. In addition, measures of belief dispersion around the announcement, determined as the standard deviation of analyst estimates, are incorporated into models 2, 4, and 6. Newey-West standard errors are shown in parantheses, where the appropriate number of lags in each case is determined using Akaike Information Criterion (AIC). ${ }^{* * *},{ }^{* *}$, and ${ }^{*}$ denote significance at the $1, \%, 5 \%$, and $10 \%$ levels respectively. 
Table 6

Robustness Test: Alternative classification of state of economy

\begin{tabular}{|c|c|c|c|c|c|c|c|c|c|c|c|c|}
\hline \multirow[b]{2}{*}{ Dependent Variable: } & \multicolumn{6}{|c|}{ Low Performing Economic Period (ICRG } & \multicolumn{5}{|c|}{ High Performing Economic Period (ICRG } & \\
\hline & Log(Volume) & & Volatility & & Returns & & Log(Volume $)$ & & Volatility & & Returns & \\
\hline & (1) & & (2) & & (3) & & (4) & & (5) & & (6) & \\
\hline Constant & 0.020 & $* * *$ & 0.057 & $* * *$ & 0.002 & & 1.556 & *** & 0.039 & $* * *$ & 0.002 & $* *$ \\
\hline & $(0.008)$ & & $(0.002)$ & & $(0.004)$ & & $(0.038)$ & & $(0.001)$ & & $(0.001)$ & \\
\hline |Neg_CPI_News/ & 0.647 & & -0.023 & & 0.005 & & -0.560 & & 0.070 & & 0.006 & \\
\hline & $(0.419)$ & & $(0.046)$ & & $(0.008)$ & & $(0.443)$ & & $(0.057)$ & & $(0.014)$ & \\
\hline |Neg_GDP_News/ & 0.084 & & 0.017 & & 0.008 & $* *$ & 3.718 & $* * *$ & 0.085 & & -0.073 & \\
\hline & $(0.073)$ & & $(0.013)$ & & $(0.004)$ & & $(0.469)$ & & $(0.321)$ & & $(0.093)$ & \\
\hline /Neg_PINC_News/ & 0.729 & & 0.010 & & -0.004 & & 2.004 & & 0.023 & & -0.008 & \\
\hline & (2.309) & & $(0.132)$ & & $(0.021)$ & & $(1.257)$ & & $(0.106)$ & & $(0.019)$ & \\
\hline |Neg_PPI_News/ & 0.587 & $* * *$ & -0.036 & $*$ & 0.011 & $*$ & 2.915 & $* * *$ & 0.338 & $* * *$ & -0.080 & $* * *$ \\
\hline & $(0.165)$ & & $(0.021)$ & & $(0.006)$ & & $(0.622)$ & & $(0.063)$ & & $(0.026)$ & \\
\hline /Neg_UNEMP_News/ & 0.460 & ** & 0.271 & $* *$ & 0.019 & & 0.117 & & 0.018 & & 0.018 & \\
\hline & (0.195) & & $(0.114)$ & & $(0.046)$ & & $(0.907)$ & & $(0.101)$ & & $(0.026)$ & \\
\hline Pos_CPI_News & 0.181 & & -0.012 & & -0.006 & & 1.308 & $* * *$ & 0.012 & & -0.015 & \\
\hline & $(0.982)$ & & $(0.022)$ & & $(0.008)$ & & $(0.292)$ & & $(0.041)$ & & $(0.011)$ & \\
\hline Pos_GDP_News & 0.949 & $* * *$ & 0.124 & $* * *$ & -0.060 & $* * *$ & 8.638 & $* * *$ & 0.269 & $* *$ & -0.030 & * \\
\hline & $(0.058)$ & & $(0.010)$ & & $(0.003)$ & & $(1.089)$ & & $(0.130)$ & & $(0.018)$ & \\
\hline Pos_PINC_News & 0.632 & & 0.015 & & -0.013 & & 0.345 & $* * *$ & 0.010 & & -0.001 & \\
\hline & $(1.571)$ & & $(0.081)$ & & $(0.011)$ & & $(0.105)$ & & $(0.013)$ & & $(0.002)$ & \\
\hline Pos_PPI_News & -0.959 & ** & 0.096 & $* * *$ & -0.021 & $*$ & 1.330 & $* * *$ & 0.082 & $* * *$ & -0.033 & $*$ \\
\hline & $(0.443)$ & & $(0.029)$ & & $(0.012)$ & & $(0.322)$ & & $(0.021)$ & & $(0.019)$ & \\
\hline Pos_UNEMP_News & 1.278 & $* *$ & 0.169 & $* *$ & -0.003 & & 0.281 & & 0.092 & & -0.015 & \\
\hline & $(0.518)$ & & $(0.083)$ & & $(0.041)$ & & (1.485) & & $(0.124)$ & & $(0.031)$ & \\
\hline CPI_Dispersion & 3.705 & & 0.139 & & 0.008 & & 1.263 & & 0.861 & * & 0.046 & \\
\hline & (3.587) & & $(0.106)$ & & $(0.029)$ & & (2.523) & & $(0.518)$ & & $(0.086)$ & \\
\hline GDP_Dispersion & 15.617 & $* * *$ & 2.048 & $* * *$ & 0.212 & $* * *$ & 13.289 & $* * *$ & 2.467 & $* * *$ & 0.283 & $* *$ \\
\hline & $(1.553)$ & & $(0.273)$ & & $(0.079)$ & & (2.935) & & $(0.752)$ & & $(0.117)$ & \\
\hline PINC_Dispersion & 2.586 & & 0.109 & & -0.076 & & 2.113 & & 0.192 & & -0.002 & \\
\hline & $(10.298)$ & & $(0.600)$ & & $(0.089)$ & & (1.897) & & $(0.150)$ & & $(0.025)$ & \\
\hline PPI_Dispersion & 2.403 & $* * *$ & 0.031 & & 0.015 & & 1.286 & & -0.017 & & 0.082 & $* *$ \\
\hline & $(0.395)$ & & $(0.024)$ & & $(0.014)$ & & $(1.309)$ & & $(0.059)$ & & $(0.033)$ & \\
\hline UNEMP_Dispersion & 19.261 & ** & 4.419 & $* * *$ & 1.148 & $* * *$ & 5.442 & & 1.230 & & 0.431 & \\
\hline & (9.692) & & $(1.626)$ & & $(0.408)$ & & $(12.644)$ & & $(0.892)$ & & $(0.427)$ & \\
\hline Lagged_Dependent & 0.898 & $* * *$ & 0.367 & $* * *$ & 0.107 & *** & 0.493 & $* * *$ & 0.463 & $* * *$ & 0.086 & $* * *$ \\
\hline & $(0.004)$ & & $(0.017)$ & & $(0.014)$ & & $(0.126)$ & & $(0.016)$ & & $(0.016)$ & \\
\hline Adj. $R^{2}$ & 0.807 & & 0.151 & & 0.014 & & 0.751 & & 0.247 & & 0.014 & \\
\hline F-Statistic & 3987.6 & & 169.5 & & 13.4 & & 3096.3 & & 335.7 & & 14.6 & \\
\hline AIC & 3.206 & & -2.369 & & -3.948 & & 3.516 & & -2.611 & & -3.665 & \\
\hline Durbin Watson Statistic & 2.770 & & 2.149 & & 2.015 & & 3.516 & & 2.229 & & 2.011 & \\
\hline
\end{tabular}

This table presents regression results forming a robustness test of the analysis presented in Table 3 . The dependent variables are the natural logarithm of volume traded $(\log$ (volume) ), realized volatility of returns, and market returns. News or surprise components of announcements for the consumer price index $(C P I)$, gross domestic product $(G D P)$, personal income $(P I N C)$, producer price index $(P P I)$, and the unemployment rate ( UNEMP) are disaggregated into negative (neg) and positive (pos) components. In addition, measures of belief dispersion around the announcement, determined as the standard deviation of analyst estimates, are incorporated. The sample period is considered as periods when the economic is performing poorly (ICRG economic risk rating $<35$ ) and periods when the economy is performing well (ICRG economic risk rating > 38.5). Newey-West standard errors are shown in parantheses, where the appropriate number of lags in each case is determined using Akaike Information Criterion (AIC).

${ }^{* * *},{ }^{* *}$, and ${ }^{*}$ denote significance at the $1, \%, 5 \%$, and $10 \%$ levels respectively. 


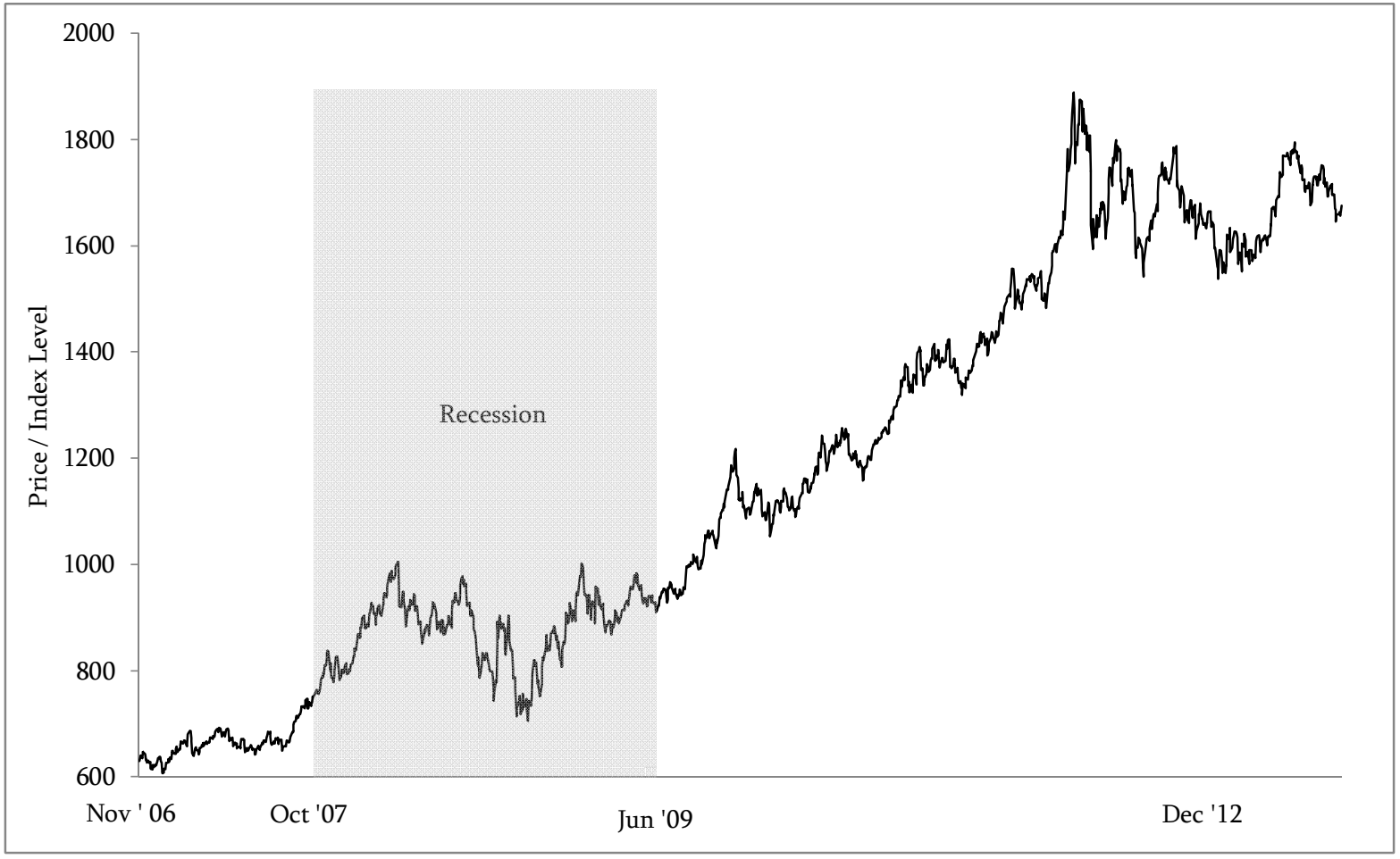

Figure 1. Evolution of gold futures price

This figure depicts the evolution of the gold futures price level for the period Nov 2006 - Dec 2012. The period of recession as designated by the NBER is also identified. 


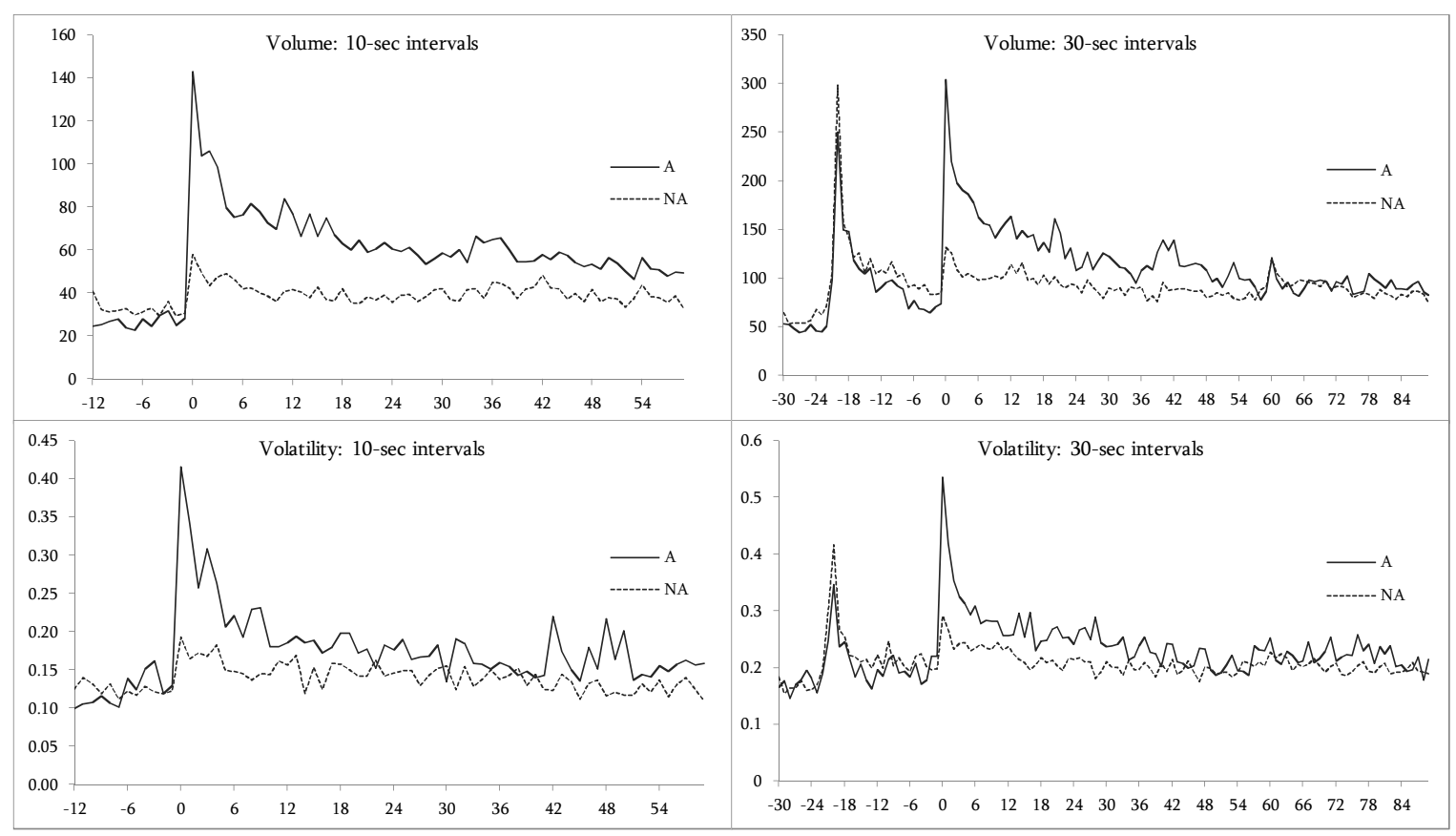

Figure 2. Volume and volatility response to major macroeconomic announcements

This figure displays the volume traded and volatility of returns in the gold futures market for the intervals surrounding major macroeconomic announcments. For 1 sec intervals the 12-min period is (-2min, $10 \mathrm{~min})$, and for 30 -sec intervals the 1-hour period is (-15 min, $45 \mathrm{~min})$. A denotes major announcement day; NA denotes non-major announcement day. 


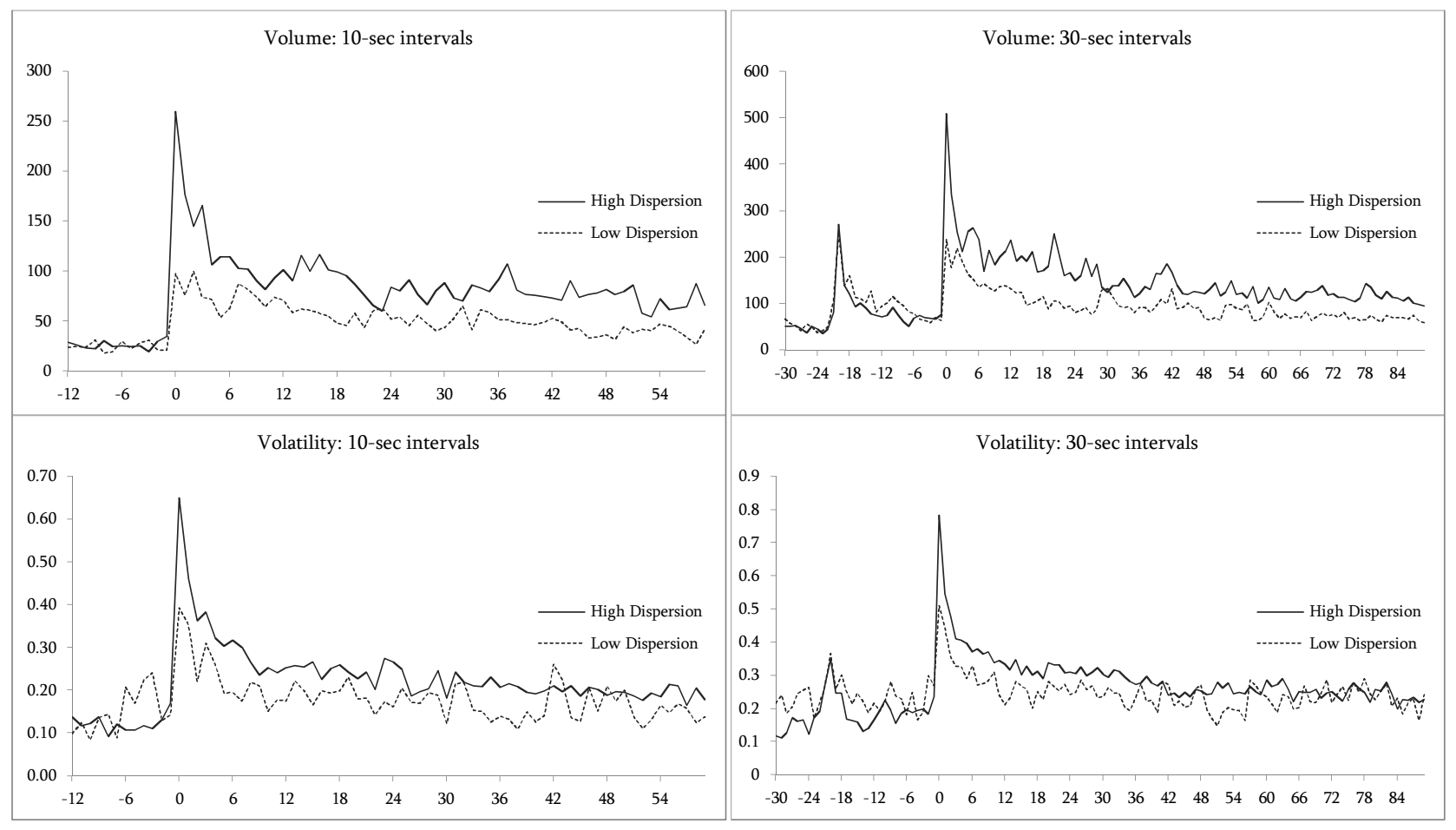

Figure 3. Volume and volatility response to major macroeconomic announcements with different dispersion of beliefs

This figure displays the volume traded and volatility of returns in the gold futures market for the intervals surrounding major macroeconomic announcments. For 10-sec intervals the 12-min period is $(-2 \mathrm{~min}, 10 \mathrm{~min})$, and for 30 -sec intervals the 1-hour period is $(-15 \mathrm{~min}, 45 \mathrm{~min})$. High dispersion indicates that the dispersion of analyst forecasts is in the highest quintile, while low dispersion indicates that the dispersion of analyst forecasts is in the lowest quintile 


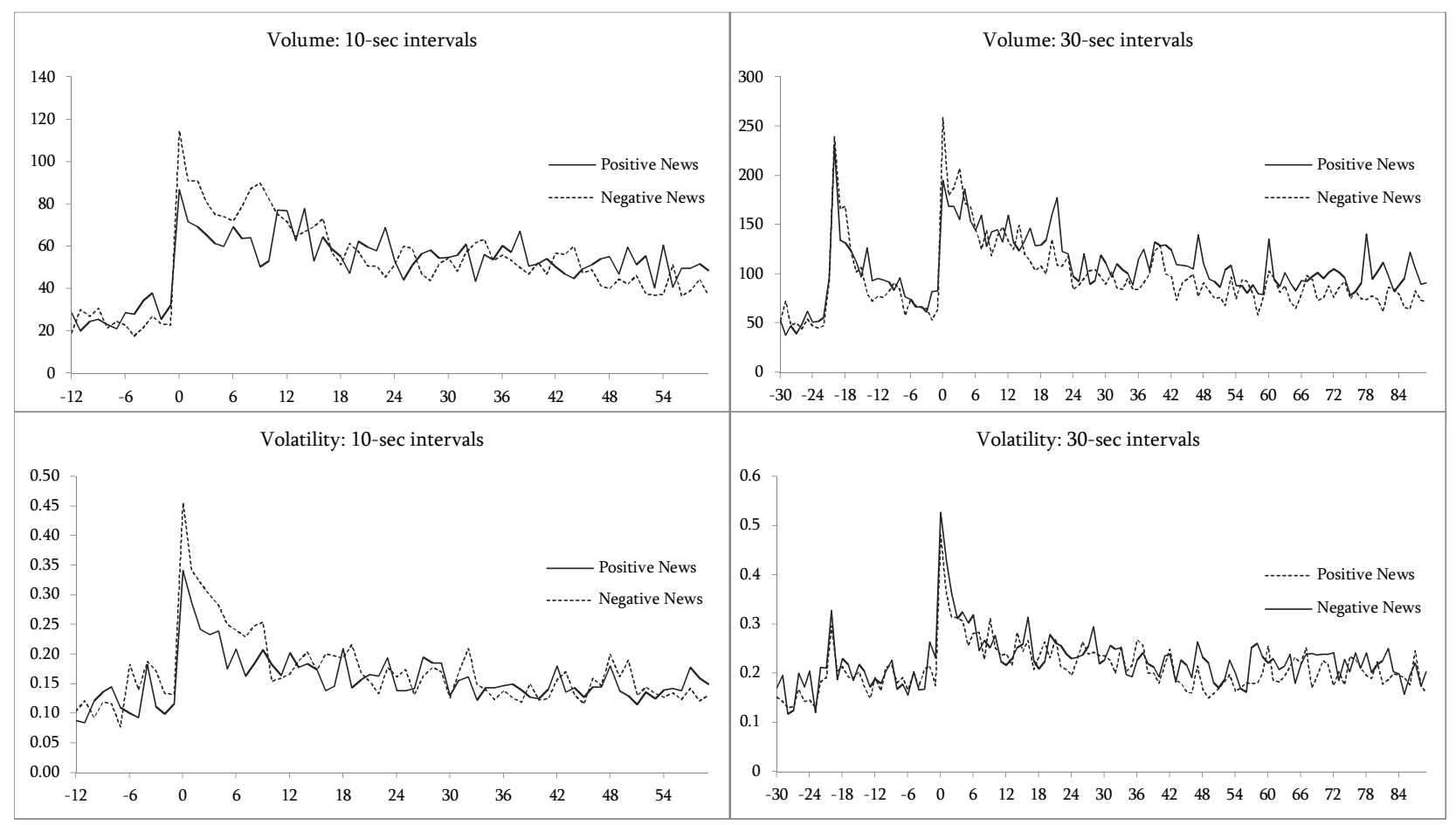

Figure 4. Volume and volatility response to disaggregated major macroeconomic announcements

This figure displays the volume traded and volatility of returns in the gold futures market for the intervals surrounding major macroeconomic announcments; where the announcements are disaggregated into positive and negative news events. For 10 -sec intervals the 12 -min period is (-2min, $10 \mathrm{~min})$, and for 30 -sec intervals the 1 -hour period is (-15min, $45 \mathrm{~min})$. 